\title{
Correction to: Process Tracing the Policy Impact of 'Indicators'
}

\author{
D. J. H. te Lintelo ${ }^{1}$ (D) T. Munslow ${ }^{2} \cdot$ K. Pittore $^{3} \cdot$ R. Lakshman $^{1}$
}

Published online: 14 November 2019

(c) The Author(s) 2019

\section{Correction to: The European Journal of Development Research https://doi.org/10.1057/s41287-019-00244-0}

Due to a production process error the original version of this paper was inadvertently published without Open Access. We apologise to the author that this was not applied before first publication. No other changes have been made to the content.

The original article has been corrected.

Open Access This article is distributed under the terms of the Creative Commons Attribution 4.0 International License (http://creativecommons.org/licenses/by/4.0/), which permits unrestricted use, distribution, and reproduction in any medium, provided you give appropriate credit to the original author(s) and the source, provide a link to the Creative Commons license, and indicate if changes were made.

Publisher's Note Springer Nature remains neutral with regard to jurisdictional claims in published maps and institutional affiliations.

The original article can be found online at https://doi.org/10.1057/s41287-019-00244-0.

D. J. H. te Lintelo

d.telintelo@ids.ac.uk

T. Munslow

tamlyn.j.munslow@durham.ac.uk

K. Pittore

katherine.pittore@wur.nl

R. Lakshman

r.lakshman@ids.ac.uk

1 Institute of Development Studies, University of Sussex, Library Road, Falmer,

Brighton BR1 9RE, UK

2 Centre for Humanities Engaging Science and Society, Durham University, Durham, UK

3 Wageningen Centre for Development Innovation, Wageningen University and Research, Droevendaalsesteeg, Wageningen 16708 PB, The Netherlands 